УДК 349.3

DOI https://doi.org/10.32849/2663-5313/2020.1.11

Ольга Бурлака,

докт. юрид. наук, дочент,

професор кафедри чивільного права і процесу

Національної академії внутрішніх справ

\title{
ЗАРУБІЖНИЙ ДОСВІД СОЦІАЛЬНОГО ЗАХИСТУ ДІТЕЙ-СИРІТ ТА ДІТЕЙ, ПОЗБАВЛЕНИХ БАТЬКІВСЬКОГО ПІКЛУВАННЯ, І МОЖЛИВОСТІ ЙОГО ВИКОРИСТАННЯ В УКРАЇНІ
}

У статті на основі аналізу наукової літератури узагальнено зарубіжний досвід сочіального захисту дітей-сиріт та дітей, позбавлених батьківського піклування, та визначено можливості його використання в Україні. Наголошено на необхідності перейняти досвід Великобританії, закріпивши на нормативному рівні Стандарти (правила) виховання дитини у прийомних сім'ях, дитячих будинках сімейного типу та інших закладах сімейного виховання дітей, що позбавлені батьківського піклування. З'ясовано, що види сочіальної допомоги в Польщі включають такі, як: допомога інвалідам і хворим; допомога малозабезпеченим; допомога престарілим; допомога особам, які знаходяться в залежності (наприклад, алкогольній чи наркотичній), та їхнім близьким; утримання і підтримка дитячих будинків, прийомних сімей, надання послуг з усиновлення, допомога сиротам або інші соиіальні послуги, адресовані дітям та молоді; організований розподіл речових дарів, одягу, продуктів харчування та фінансової підтримки; утримання притулків для бездомних або допомога їм іншим способом; допомога жертвам стихійних лих; допомога біжениям. Зроблено висновок, що перспективними заходами та напрямами впровадження в Украӥні позитивного зарубіжного досвіду у сфері сочіального захисту сім'ї, дитинства, материнства та батьківства є такі: запровадити інтенсивний процес деінституиіалізації опіки над дітьми, що позбавлені батьківського піклування (діти-сироти, інші категорії дітей), та не лише декларувати, а й реалізувати пріоритетність форм сімейного виховання дитини; стимулювати створення прийомних сімей, дитячих будинків сімейного типу, а також народжуваність дітей шляхом запозичення досвіду Німеччини та Польщі та надання істотних податкових пільг, відсоток яких зростатиме пропориійно кількості народжених (взятих на виховання чи під сімейну опіку дітей); перейняти досвід Великобританії, закріпивши на нормативному рівні Стандарти (правила) виховання дитини у прийомних сім'ях, дитячих будинках сімейного типу та інших закладах сімейного виховання дітей, що позбавлені батьківського піклування.

Ключові слова: зарубіжний досвід, соціальний захист, діти-сироти, діти, позбавлені батьківського піклування.

Постановка проблеми. Поглиблення процесу європейської інтеграції України стало можливим завдяки насамперед підписанню Угоди про асоціацію між Україною та Європейським Союзом, що стане одним з інструментів структурних змін у національній правовій системі. Насамперед такі зміни стосуватимуться якості законодавства, яке сьогодні страждає чисельними посиланнями на підзаконні нормативно-правові акти, без належного регулювання організаційних та процедурних аспектів чинності законів. У таких умовах роль порівняльного правознавства полягає у забезпеченні взаємодії та співпраці представників різних правових культур, забезпеченні зближення національних законодавств та однакового вирішення юридичних справ на засадах справедливості, рівності і недискримінації. Такі завдання вирішує порівняльне правознавство, яке є не лише юридичною наукою, але й практичним інструментом. Знаходження спільних та відмінних рис у правових культурах, традиціях, національних правопорядках не є самоціллю порівняльного правознавства. Це є лише необхідною передумовою для пошуку оптимальних рішень конкретних юридичних проблем на рівні як законодавчої роботи, так і ухвалення судових рішень, здійснення конкретних юридичних процедур. У рамках окресленої проблематики цікавим є насамперед досвід вирішення у зарубіжних країнах проблеми дітей-сиріт та дітей, позбавлених батьківського піклування, створення та функціонування системи опіки над ними, принципи побудови такої системи опіки. 
Стан дослідження. У наукових дослідженнях висвітлено чимало питань із цієї проблематики. До розгляду деяких аспектів соціального захисту населення в країнах СС зверталися вітчизняні та зарубіжні науковці, такі як: В. Антропов, М. Кашуба, Р. Корнюшина, Л. Смола, В. Чепінога, Г. ЕспінгАндерсен, А. Розеншон та інші. Велика увага в цих роботах приділялася соціальній політиці у сфері соціального захисту населення. Вивченню зарубіжного досвіду соціального захисту сімей присвячені праці Л. Крамаренка та С. Ничипоренко. Однак малодослідженим є зарубіжний досвід соціального захисту дітей-сиріт та дітей, позбавлених батьківського піклування, створення та функціонування системи опіки над ними, принципи побудови такої системи опіки.

Мета статті - дослідити зарубіжний досвід соціального захисту дітей-сиріт та дітей, позбавлених батьківського піклування, та визначити можливості його використання в Україні.

Виклад основного матеріалу. Починати наукове дослідження слід із розгляду досвіду Великобританії де процес деінституціалізації розпочався одразу після закінчення Другої світової війни. Пріоритети державної політики у сфері соціального захисту посиротілих дітей підтверджуються такими статистичними даними: в Англії інституційна форма опіки у 2005 році становила 11 \%, Шотландії та Північній Ірландії - 13 \%, Уельсі - $6 \%$. А в Україні для порівняння у 2005 році зазначений показник становив $32 \%$ від загальної кількості сиріт. При цьому слід зазначити, що у Великобританії, а також Норвегії, Ісландії новонароджених дітей і дітей молодшого віку взагалі не розміщують у дошкільних закладах. Звичайно, інституційний догляд за дітьми існував у більшості країн світу в різні часи як спосіб піклування про дітей. Однак численні дослідження вказують на те, що форми догляду на основі родини та громади $є$ ефективнішими у задоволенні потреб дитини, тоді як інституційний догляд знижує життєві можливості дитини і навіть тривалість життя. Діти в інституціях частіше відчувають проблеми 3 навчанням, а в підлітковому віці в них погані трудові перспективи. Крім того, в інституціях неможливо гарантувати дотримання базових прав людини. Як свідчить досвід деінституціалізації ряду країн, цей процес є благотворним як для дітей та їхніх родин, так і для громад і урядів, як зазначає О. Мордань [1, с. 75].

Щодо Великобританії, то слід відзначити, що вона має понад столітню історію соціаль- ної роботи, соціального захисту дітей-сиріт i дітей, позбавлених батьківського піклування. Буде доречним проаналізувати основні форми влаштування такої категорії дітей та визначити найбільш ефективні, щоб урахувати досвід саме цієї країни для вдосконалення системи соціального захисту дітей в Україні. Інститут фостерних сімей виник у XVI ст. В Англії у 1562 р. було прийнято Закон про бідних, який визначив порядок розміщення в прийомні сім'ї дітей, які залишилися без піклування батьків, до повноліття. Тоді дітей, зазвичай дітей-сиріт або підкидьків, передавали на виховання як помічників майстра в бажаючу сім'ю. Там діти працювали по господарству. Таку опіку було визначено у Законі про бідних у 1601 р. - першому великому законодавчому акті, що регулював сферу соціального захисту в Англії.

Вважалося, що залучення сиріт до праці не тільки вирішує проблему бездоглядності і бідності, а й служить своєрідним моральним вихованням для дітей бідняків. У ХІХ ст. суспільство поступово схилялося в бік закладів опіки. У 1834 р. у поправках до Закону про бідних було запроваджено поняття «промислове навчання» у великих закладах закритого типу, побудованих з метою навчити дітей не лише корисних навичок, а й самодисципліни. Підлітків посилали в «промислові школи» за жебрацтво, бродяжництво і скоєння правопорушень. Пізніше, у XIX ст., соціальні реформи і зростаюча критика закостенілого і безособового середовища закладів опіки призвели до повторної практики «поселення в чужу сім’ю». Вікторіанський соціальний реформатор і засновник відомої дитячої благодійної організації Томас Барнадо був переконаний, що сім'я $є$ найпридатнішим середовищем для виховання дитини. Він створив модель, за якою діти, позбавлені батьківської опіки, проживали і виховувалися в почесних сім'ях на селі. Він також запровадив модель догляду за немовлятами неодружених жінок. Таких матерів влаштовували домашніми служницями, вони мали змогу бачитися зі своїми дітьми у вільний від роботи час [2, c. 12$]$.

Незважаючи на цю інноваційну практику, на початку XX ст. 70-80 тис. дітей все ще перебували під опікою в закладах різного типу, тоді як лише близько 10 тис. дітей проживали в нерідних сім'ях. Але одне із нововведень Вікторіанської доби, а саме дитяча еміграція, яка повинна була стати радикальним вирішенням проблем дітей міської бідноти, піддалося сильній критиці, особливо 3 боку дорослих, які самі ще дітьми пройшли крізь це. Воно передбачало виселення соціально незахищених дітей на територію 
Британських колоній, таких як Канада і Австралія, що мало на меті дати дітям «нову перепустку» в життя. Таким чином дітей виселяли, починаючи з XVII ст., але це явище стало масовим лише після 1860 року За підрахунками, з 1870 і до 1967 рр. щонайменше 150 тис. дітей було вислано за кордон у такий спосіб, більшість із них повністю втратили зв'язок $з$ рідними. Застосування такої практики мотивувалося бажанням врятувати дітей від загниваючого впливу міського життя в Британії. Це був один зі способів уникнути витрат на утримання дітей під тривалою опікою, а також метод збільшення британського населення в колоніях. Дітей переважно відсилали на проживання у нові сім'ї, а деякі із самого початку потрапляли в заклади опіки.

Така практика залишалася незмінною аж до Другої світової війни, поки акцент не змістився в бік пошуків можливостей для утримання дітей у рідних сім'ях, а останніх - у суспільстві. Британське суспільство пережило масову воєнну евакуацію, коли дітей висилали з міст у села, щоб уникнути бомбардування. Дітей поселяли в чужі сім'ї навмання, оскільки не вистачало ні часу, ні ресурсів для проведення обстеження сімей чи підбору дітей в сім'ї таким чином, щоб максимально задовольнити їхні потреби. У результаті багато дітей проживали у невідповідних сім'ях, деякі з них пройшли через недбале ставлення і експлуатацію [3]. Після закінчення Другої світової війни в багатьох європейських країнах, зокрема Великій Британії, на державному рівні розроблялися програми влаштування дітей-сиріт та підлітків з неблагополучних родин до нових сімей для перевиховання та соціалізації. Однак знадобилися десятиліття для правового впорядкування, розвитку та вдосконалення інституту прийомних сімей [2, с. 13].

Натепер система фостерних сімей успішно функціонує та розвивається у Великобританії. Більшість дітей, які з різних причин опинилися без батьківського піклування, проживають не в дитячих будинках, а саме в таких прийомних родинах. Правове регулювання цього інституту забезпечує Закон про дітей. Цей документ вперше закріпив термін «батьківська відповідальність» (parental responsibility), під якою розуміють «всі права, обов'язки, моральні зобов'язання, функції, відповідальність і повноваження батьків дитини при спілкуванні з нею і поводженні з її майном, закріплені законодавчо». До фостерних сімей потрапляють діти, які не досягли 16 років. у фостерній сім'ї не можуть перебувати більше трьох дітей. Винятком із цього пра- вила можуть бути випадки, коли рідні брати і сестри, кількість яких перевищує зазначену, потребують опіки. Крім Закону про дітей, існують також загальні інструкції про влаштування дітей (Arrangements for Placement of Children (General) Regulations) і Правила влаштування дітей на фостерне виховання (Foster Placement (Children) Regulations), нормативні акти більш детально регламентують процес розміщення дитини у фостерній сім'ї з урахуванням різноманітних життєвих ситуацій і обставин [4].

у 1999 р. Національна асоціація фостерної опіки Великобританії (NFCA) підготувала і опублікувала Національні стандарти фостерного виховання у Великобританії. На додаток до Національних стандартів робочою групою Національної асоціації фостерного виховання Великобританії (NFCA) були підготовлені ще два документи: Звіт i рекомендації Робочої групи Великобританії, що стосуються фостерного виховання, і Кодекс процедур з відбору, оцінки підготовки та підтримки фостерних вихователів. Таким чином, ефективне законодавче регламентування альтернативного сімейного влаштування дітей в Англії сприяє результативності його функціонування. У Великій Британії діє 150 державних служб оцінки потреб і планування надання соціальних послуг, до обов'язків яких входить визначення потреб, призначення соціальних послуг, соціальної допомоги. Сутність їхньої діяльності полягає в тому, щоб з метою забезпечення отримання клієнтами насправді потрібних їм послуг формувати системи різноманітних соціальних служб, розробляти гнучкі схеми надходження коштів. Найвідомішою з недержавних організацій у Великій Британії є Національне товариство попередження жорстокого ставлення до дітей (NSPCC) [5, c. 164].

У Великій Британії немає значної кількості будинків-інтернатів для дітей. У деяких місцевостях трапляються лише невеликі школи-інтернати. Поширеним є перебування дитини на короткостроковому проживанні. Найпопулярніша форма - foster families (foster 3 англійської означає «виховувати (чужу дитину); передавати дитину на виховання; сприяти розвитку, заохочувати»). Вони розглядаються як прийомні сім'ї, де виховується до 80 \% усіх дітей, позбавлених батьківського піклування. Обсяг соціальної допомоги на дитину визначається індивідуально і залежить від комплексу наданих послуг відповідно до індивідуальних потреб. Задля забезпечення достатньої кількості фостерних вихователів на рівні держави створено мережу спеціальних фостерних 
агентств, що реалізують дві головні функції - пошук і підготовку потенційних вихователів; створення комплексу безоплатних послуг для дітей-сиріт і вихователів. У Великій Британії понад 76 \% дітей, які потребують опіки, перебувають у фостерних сім'ях.

Другий вид фостерингу - це приватна домовленість між батьками та фостерними вихователями про опіку над дитиною, що здійснюється в будинку опікуна без залучення органів місцевої влади. Дослідження, що було проведене командою науковців у Британії, показало, що близько половини дітей, які потребують догляду, мають бути влаштовані у фостерні сім'ї. Таким чином, можна підсумувати, що влаштування дитини у родину є найбільш ефективною формою влаштування дитини, яка потребує опіки [6, с. 133-134].

Цікавим є досвід США, де ще в 1909 році критикувалися великі інтернатні заклади, які поширилися в США наприкінці XIX ст. - на початку XX ст. завдяки міграції. Супротивники такої форми виховання критикували заклади за велику вартість порівняно з прийомними сім'ями, які вже існували на той час. Того ж року на державному рівні було вирішено відмовитися від системи інтернатних закладів. Натомість першочерговими заходами було визначено дії з підтримки рідних сімей вразливих дітей перед їх влаштуванням у прийомні сім'ї, а інтернатні заклади використовувалися лише у разі особливих обставин. Стрімке зменшення кількості дітей в інтернатних закладах США розпочалося в кінці 1930-х років. Цьому сприяло прийняття у 1937 році Закону про соціальний захист (Social Security Act), який забезпечив надання фінансової підтримки сім'ям 3 дітьми, які потрапили у складні життєві обставини. Завдяки цьому закону наступні 60 років кількість дітей в інтернатах поступово зменшувалося приблизно на 1-2 \% щороку.

У Швеції процес деінституціалізації дітей розпочався в середині $50-$ х років минулого століття. Хоча в цій країні політика державного утримання дітей ніколи не була на першому плані: діти, які з різних причин не можуть проживати в рідній сім'ї, переважно влаштовувалися в дитячі будинки сімейного типу. Нині близько 75 \% державних дитячих будинків у Швеції опікуються не більше як 9 дітьми одночасно, а їх перебування обмежується коротким проміжком часу.

Міжнародні експерти у сфері соціального захисту дитинства стверджують, що процеси деінституціалізації, які сьогодні тривають як в Україні, так і в інших країнах СНД та Східної Європи, - це синонім докорінної пере- будови старої системи соціального захисту вразливих сімей і дітей. Адже успадкована система, зосереджуючись на інтернатних закладах, нехтувала роллю сім'ї в розвитку дитини і замінювала іï державною опікою не лише для дітей-сиріт, а й для дітей з розладами поведінки та особливими потребами. До масштабної інституціалізації дітей призвела й практика, коли замість підтримки батьків як засіб впливу широко використовували позбавлення батьківських прав [1, с. 76].

Для вирішення значних проблем цікавим видається досвід Польщі, яка має давні витоки опікунсько-виховних інституцій. Так, вже в кінці середньовіччя система допомоги дітям-сиротам була добре розбудована. Опіку, допомогу та підтримку можна було отримати в різних інституціях. Занедбаними дітьми і сиротами займалися лікарні для дорослих, заклади опіки при парафіях.

Сучасна Польща має цікавий підхід до соціального захисту. Види соціальної допомоги включають такі, як: допомога інвалідам і хворим; допомога малозабезпеченим; допомога престарілим; допомога особам, які знаходяться в залежності (наприклад, алкогольній чи наркотичній), та їх близьким; утримання і підтримка дитячих будинків, прийомних сімей, надання послуг з усиновлення, допомога сиротам або інші соціальні послуги, адресовані дітям та молоді; організований розподіл речових дарів, одягу, продуктів харчування та фінансової підтримки; утримання притулків для бездомних або допомога їм іншим способом; допомога жертвам стихійних лих; допомога біженцям. При цьому особа може одержувати одночасно декілька видів повноцінних допомог без обмежень [7].

Категорія дітей-сиріт та дітей, позбавлених батьківського піклування, серед соціально вразливої верстви населення законодавчо не виділяється. Основним нормативно-правовим актом у сфері соціального захисту дітей-сиріт Польщі є Закон Республіки Польща «Про соціальну допомогу», однак він містить загальні, декларативні положення. Лише статтею 7 визначено, що дітям-сиротам надається соціальна допомога. Допомога надається в двох формах: грошовій та натуральній, де до останньої належать одяг, продукти харчування [8]. Також існує таке поняття, як «сімейна рента» - це грошова виплата, що надається дітям у разі втрати одного чи обох батьків. Дана допомога становить 460 доларів. Чисельність дітей-сиріт не фіксується, тому офіційні дані відсутні [7].

Але найбільш вартою для запозичення Україною є наявність в Польщі різноманіт- 
них центрів для підтримки соціально незахищених громадян. Щодо дітей-сиріт, то існує нова модель установ, де одночасно проживають 12-14 дітей, з якими працюють 4-5 вихователів. Установа передбачена для тимчасового перебування дітей, поки не буде знайдено для них нову родину. Інша форма виховання - спеціалізовані соціальні гуртожитки для проживання до 30 осіб. Повноваження з улаштування цієї форми делеговані державою громадським організаціям [9]. Місцева влада схвалює співпрацю неурядових інституцій, що створюють соціальні центри, надають підтримку соціально не захищеним верствам населення, та намагається всіляко їм допомагати. Кожна із організацій працює з певною категорією осіб, надаючи їм різноманітну допомогу (психологічну, соціальну, юридичну, матеріальну).

Законодавчим актом, що регулює діяльність неурядових організацій в Польщі, є Закон «Про діяльність громадської користі та волонтерство», прийнятий 24 квітня 2003 року. Відповідно до даного закону, діяльністю громадської користі визнається суспільно корисна діяльність, що ведеться громадськими організаціями у сфері громадських завдань, а саме у сфері соціальної допомоги, благодійної діяльності. Також в ньому зазначено, що органи громадської адміністрації проводять діяльність у сфері громадських завдань у співпраці з громадськими організаціями та суб'єктами, які ведуть діяльність громадської користі відповідно до території та завдань, що належать до компетенції органів громадської адміністрації. Органи громадської адміністрації замовляють громадським організаціям виконання певних громадських завдань, в тому числі й у сфері соціального захисту, з повною чи частковою фінансовою підтримкою. Що стосується питання фінансування діяльності громадських організацій, створених ними центрів чи світлиць, великим плюсом є те, що кожен платник податку в Польщі кожного місяця може надсилати 1 \% від суми свого податку на рахунок громадської організації [10, с. 182-184].

Підводячи підсумки, автори доходять висновку про те, що для сфери соціальногозахисту дітей-сиріт та дітей, позбавлених батьківського піклування, в Україні необхідно запозичити такий досвід та внести відповідні зміни:

1) оскільки зайнятість для кожної особи має вагоме місце в житті, в тому числі для прийняття рішення щодо всиновлення, державі необхідно проводити належну професіоналізацію прийомних вихователів, здійснювати достатню фінансову підтримку для вирішення проблем з безробіттям та проводити щодо цього питання інформаційну кампанію;

2) посилити соціальну рекламу зі сприяння сімейним формам виховання;

3) делегувати із центрів соціальних служб деякі повноваження у сфері соціального захисту дітей-сиріт громадським організаціям;

4) започаткувати співпрацю неурядових інституцій з органами державної влади та місцевого самоврядування шляхом замовлення останніми певних громадських завдань, в тому числі й у сфері соціального захисту дітей-сиріт, з повною чи частковою фінансовою підтримкою, що одночасно буде сприяти зайнятості населення;

5) популяризувати інформацію про можливість здійснювати благодійні внески на рахунок громадських організацій, що здійснюють діяльність у сфері соціального захисту дітей-сиріт та дітей, позбавлених батьківського піклування [10, с. 183].

\section{Висновки}

Підсумовуючи наведене, аналізуючи позитивний зарубіжний досвід у сфері соціального захисту сім'ї, дитинства, материнства та батьківства, слід виділити такі перспективні заходи та напрями його впровадження в межах України:

- необхідно запровадити інтенсивний процес деінституціалізації опіки над дітьми, що позбавлені батьківського піклування (діти-сироти, інші категорії дітей), та не лише декларувати, а й реалізувати пріоритетність форм сімейного виховання дитини;

- стимулювати створення прийомних сімей, дитячих будинків сімейного типу, а також народжуваність дітей шляхом запозичення досвіду Німеччини та Польщі та надання істотних податкових пільг, відсоток яких зростатиме пропорційно кількості народжених (взятих на виховання чи під сімейну опіку дітей);

- перейняти досвід Великобританії, закріпивши на нормативному рівні Стандарти (правила) виховання дитини у прийомних сім'ях, дитячих будинках сімейного типу та інших закладах сімейного виховання дітей, що позбавлені батьківського піклування.

\section{Список використаних джерел:}

1. Мордань О. Міжнародна практика реформування державної системи опіки: досвід для України. Державне управління та місиеве самоврядування : зб. наук. праць. 2012. № 2. С. 75-85.

2. Деінституалізація та трансформація послуг для дітей : посібник з найкращих практик / 
під ред. Жоржетти Мюльгейр, Кевіна Брауні. 143 с. URL: www.cam-z.org/biblioteka 11/ socialnij_zaxis_49/deinstitualizac_53.html. (дата звернення: 02.12.2019).

3. Грищенко С. Розвиток інституту прийомної сім'ї: огляд міжнародного та національного досвіду. Вісник представниитва EVERYCHILD в Україні. 2003. № 1. С. 18-22.

4. Манжула Е. В. Гражданско-правовое регулирование деятельности семейных воспитательных групп : монография. Москва, 2010.83 c.

5. Фостерна сім'я у Великобританії: основні засади діяльності. Освіта і управління. 2002. № 1. С. $163-170$.

6. Пушкіна О. В., Лозицька С. М. Прийомні (фостерні) сім'ї: американський досвід. Вісник Дніпропетровського університету імені
Альфреда Нобеля. Серія «юридичні науки». 2013. № 2 (5). С. 132-136.

7. Соціальний захист населення в Польщі. URL : http://www.pilga.in.ua/node/18 (дата звернення: 02.12.2019).

8. Ustawa o pomocy społecnej // Kancelaria Sejmu z dnia 12 marca 2004 r. Str. 1-79.

9. Доля І. Упровадження ефективних форм виховання в системі державної та сімейної опіки: міжнародний досвід та уроки для України. URL : http:// old.niss.gov.ua/monitor/March08/04. htm. (дата звернення: 02.12.2019).

10. Кисельова О. І. Актуальні питання соціального захисту дітей-сиріт та дітей, позбавлених батьківського піклування в порівняльному аналізі України та Польщі. Науковий вісник Ужгородського національного університету. Серія «Право». 2014. № 24 (Том 2). С. 181-184.

The article, based on the analysis of scientific literature, summarizes the foreign experience of social protection of orphans and children deprived of parental care, and identifies the possibility of its use in Ukraine. Emphasis is placed on the need to take on the UK experience by laying down, at the normative level, the Standards (rules) for the upbringing of children in foster care, family-type orphanages and other parental care facilities. It has been found that types of social assistance in Poland include: assistance to the disabled and the sick; assistance to the needy; assistance for the elderly; assistance to addicted persons (such as alcohol or narcotics) and their relatives; maintenance and support of orphanages, foster care, adoption services, assistance to orphans or other social services addressed to children and young people; organized distribution of gifts, clothing, food and financial support; maintenance of or assistance to the homeless or otherwise; assistance to victims of natural disasters; assistance to refugees. It is concluded that the perspective measures and directions of introduction of positive foreign experience in the field of social protection of the family, childhood, motherhood and paternity within Ukraine are as follows: to introduce an intensive process of deinstitutional custody of children deprived of parental care, other child care. categories of children), not only to declare, but also to realize the priority of forms of family upbringing of the child; to encourage foster families, family-type orphanages, and the birth rate of children by borrowing from the experience of Germany and Poland and providing substantial tax benefits, the percentage of which will increase in proportion to the number of births (taken care of or under the care of children); to take over the UK experience by establishing at the regulatory level Standards (rules) for the upbringing of children in foster care, family-type orphanages, and other family-based childcare facilities.

Key words: foreign experience, social protection, orphans, children - deprived of parental care. 